\title{
First records of Freshwater Bivalves of Ilha Grande National Park, Paraná, Brazil
}

\author{
Flávio Henrique Ragonha ${ }^{1}$, Gisele Daiane Pinha ${ }^{1}$, Danielle Katharine Petsch ${ }^{1}$, \\ Maria Cristina Dreher Mansur² \& Alice Michiyo Takeda ${ }^{3}$
}

\begin{abstract}
1. Programa de Pós-Graduação em Ecologia de Ambientes Aquáticos Continentais, Universidade Estadual de Maringá, Av. Colombo, 5790, $87020-900$ Maringá, PR, Brazil. (flaviohragonha@yahoo.com.br; pinhagisele@hotmail.com; dannypetsch@hotmail.com)

2. Universidade Federal do Rio Grande do Sul, Instituto de Biociências, Centro de Ecologia, Av. Bento Gonçalves, 9500, 91501-970 Porto Alegre, RS, Brazil.(mcrismansur@gmail.com)

3. Universidade Estadual de Maringá, Departamento de Biologia, Núcleo de Pesquisas em Limnologia, Ictiologia e Aquicultura, Av. Colombo, 5790, $87020-900$ Maringá, PR, Brazil. (alicemtakeda@yahoo.com.br)
\end{abstract}

\begin{abstract}
The Ilha Grande National Park, Paraná, Brazil, is located in the Upper Paraná River and has characteristics typical of a floodplains. This protected area includes lagoons connected and disconnected to the Paraná River, although the latter also connect during periods of high water level, thus composing a heterogeneous group of lacustrine environments. The enormous potential the flora and fauna diversities are still little known to the region, as can be seen through benthic invertebrates, inclunding bivalves mollusks. The granulometric composition of these floodplain lagoons was formed mainly by mud and very fine sand. Furthermore, organic matter composition was predominantly of fine particulate. The other abiotic factors differed from lagoons located within the island of the park to those located in the left margin of Paraná River. The results demonstrated the importance of abiotic factors such as the physical composition of granulometric texture, organic matter and macrophyte banks, to the establishment of bivalves in these floodplain lagoons. We recorded bivalves of Pisidium (native), Diplodon (native), and Corbicula (invasive). The highest values of Diplodon sp. density were observed at São João/C lake, for Pisidium sterkianum (Pilsbry, 1897) at São João/M lake, and to Jatobá/C lagoon with high density of invasive species Corbicula fluminea (Müller, 1774). This study to obtain conduct the first records of freshwater bivalves in floodplains lagoon in the Ilha Grande National Park, and provides contributions to better understanding the ecology of these mollusks. The recording of native species in the region of Upper Paraná River floodplain after a lomg period without new records, demonstrated the importance of protecting the lagoons of the Ilha Grande National Park as they can be a possible refuge to some species of native freshwater bivalves.
\end{abstract}

KEYWORDS. Floodplains, lagoons, native species, invaders.

RESUMO. Bivalves límnicos do Parque Nacional de Ilha Grande, Paraná, Brasil. O Parque Nacional de Ilha Grande (Paraná, Brasil) é localizado no Alto Rio Paraná e apresenta características típicas de uma planície de inundação. Essa área de proteção ambiental inclui uma heterogeneidade de ambientes lacustres, dentre estes lagoas conectadas e não conectadas ao rio Paraná. Os enormes potenciais de diversidade tanto de flora quanto de fauna são ainda pouco conhecidos para o local, como para os invertebrados bentônicos, e dentre eles, os moluscos bivalves. A composição granulométrica das lagoas foi constituída basicamente de sedimentos mais finos, como lama e areia muito fina, e a matéria orgânica composta predominantemente por partículas finas. Também observamos diferenças espaciais nos fatores limnológicos, separando as lagoas situadas dentro da ilha do parque, das contidas na margem esquerda do rio Paraná. Esses dados demonstraram a importância dos fatores físicos como composição da textura granulométrica, matéria orgânica e bancos de macrófitas para o estabelecimento dos bivalves nesses ambientes. Registramos bivalves de Pisidium (nativa), Diplodon (nativa) e Corbicula (invasora). Os maiores valores de densidade média foram observados para Diplodon sp. na lagoa São João/C, para Pisidium sterkianum (Pilsbry, 1897) na lagoa São João/M, e para a espécie invasora Corbicula fluminea (Müller, 1774) na lagoa Jatobá/C. Esse estudo teve como objetivo realizar o primeiro levantamento de bivalves límnicos em lagoas de inundação do Parque Nacional da Ilha Grande, além de fornecer subsídios para melhor compreensão da ecologia desses moluscos. O registro de espécies nativas, após um longo período sem ocorrência na região da planície de inundação do alto rio Paraná, demonstrou a importância da proteção das lagoas do Parque Nacional de Ilha Grande para a manutenção dos mesmos, podendo assim ser um possível refúgio para algumas espécies de bivalves límnicos nativos.

PALAVRAS-CHAVE. Planícies de inundação, lagoas, espécies nativas, espécies invasoras.

Ilha Grande National Park consists by a fluvial archipelago, which comprises hundreds of islands, located in the southern of the Upper Paraná River Floodplain. This region shows the last remaining stretch of the Paraná River floodplain in Brazil (ICMBio, 2008), free of impoundments. The 78,875 hectares are included in the complex ecosystem that integrate the Biodiversity Corridor of the Paraná River. The National Park was created in 1997 as a project of the IAP (Instituto Ambiental do Paraná) developed by IBAMA (Instituto Brasileiro do Meio Ambiente e dos Recursos Naturais Renováveis) and many cities that compose the CORIPA (Consórcio Intermunicipal para a Conservação do Rio Paraná e Áreas de Influência). The wetlands, lakes and its surroundings, comprise a great diversity of fauna and flora that are still little known (ICMBio, 2012), such as benthic invertebrates.
In freshwater bodies, benthic invertebrates are diverse and abundant, but generally exhibit a clumped distribution and are relatively difficult to sample, especially when they live in deep subsurface sediments. Thus, the benthic species richness of freshwater generally is unnoticed until unexpected changes occur in ecosystems (Covich et al., 1999). In this context, bivalves (clams and mussels) are among the most familiar of aquatic organisms. Bivalves have been used by humans for many centuries as important sources of food and ornament. It is only recently, however, that ecologists have begun to understand that bivalves also play many important roles in ecosystems. Furthermore, recently, some species were considered economically important pests, by fouling water intakes and other structures (e.g., DAME, 1996).

For Brazil, are estimated about 22 genera with 114 
species of freshwater bivalves mollusks, and of these, only five species ( $4 \%$ of total) are considered as invasive species. Despite the low representation of invasive species, they can promote great impacts both ecological and economic (Pereira et al., 2012). Therefore, biological invasions are attracting a growing importance, and are considered as the second biggest cause of biodiversity loss, surpassed only by the fragmentation and loss of habitats (VITOUSEK et al., 1996; MACK et al., 2000).

Conservation status of native species of freshwater bivalve is increasing concern mainly because this group have suffered a great population decline due to different human activities affecting the freshwater ecosystems. Between the human activities that promoted the loss of these species, we can mention the habitat destruction, eutrophication, impoundments, population changes and migration routes of fish community and the competition for resources and habitat with species of freshwater mollusks invaders (PEREIRA et al., 2012).

Considering the importance of the current state of the bivalves fauna to assess the diversity and community composition, our study aimed conduct the first records of freshwater bivalves (native and invasive) in floodplains lakes of Ilha Grande National Park.

\section{MATERIALS AND METHODS}

Study Area. The Paraná River is the tenth largest river in the world regarding the discharge and occupies the second largest watershed in South America (Stevaux et al., 2004). The Ilha Grande National Park ( 78,875 ha) is located between states of Paraná and Mato Grosso do Sul (23 $15^{\circ}$, to $24^{\circ} 05^{\prime} \mathrm{S}$ and $53^{\circ} 40^{\prime}$ to $54^{\circ} 17^{\prime} \mathrm{W}$ ) (Fig. 1). The floodplain lakes occupy the most depressed parts from the inactive or active secondary channel and areas of the floodplain basin. These lakes may maintain constant or intermittent connections with the channels, or may be fed exclusively by the groundwater, with river water entering only during flood periods. Sediment in these environments is dominated by mud and organic matter. The high water period of the Paraná River occurs between November and March and produce different effects according to the intensity. The low water period (dry season) usually occurs between April and October. The average temperature is $22^{\circ} \mathrm{C}$ and the precipitation is about 1200 to $1300 \mathrm{~mm}$ per year.

To characterize freshwater bivalves from the Ilha Grande National Park, five floodplain lakes (Saraiva, Jatobá, São João, Jacaré and Xambrê) were sampled along a stretch of $35 \mathrm{~km}$ (Fig. 1). Saraiva is a natural floodplain

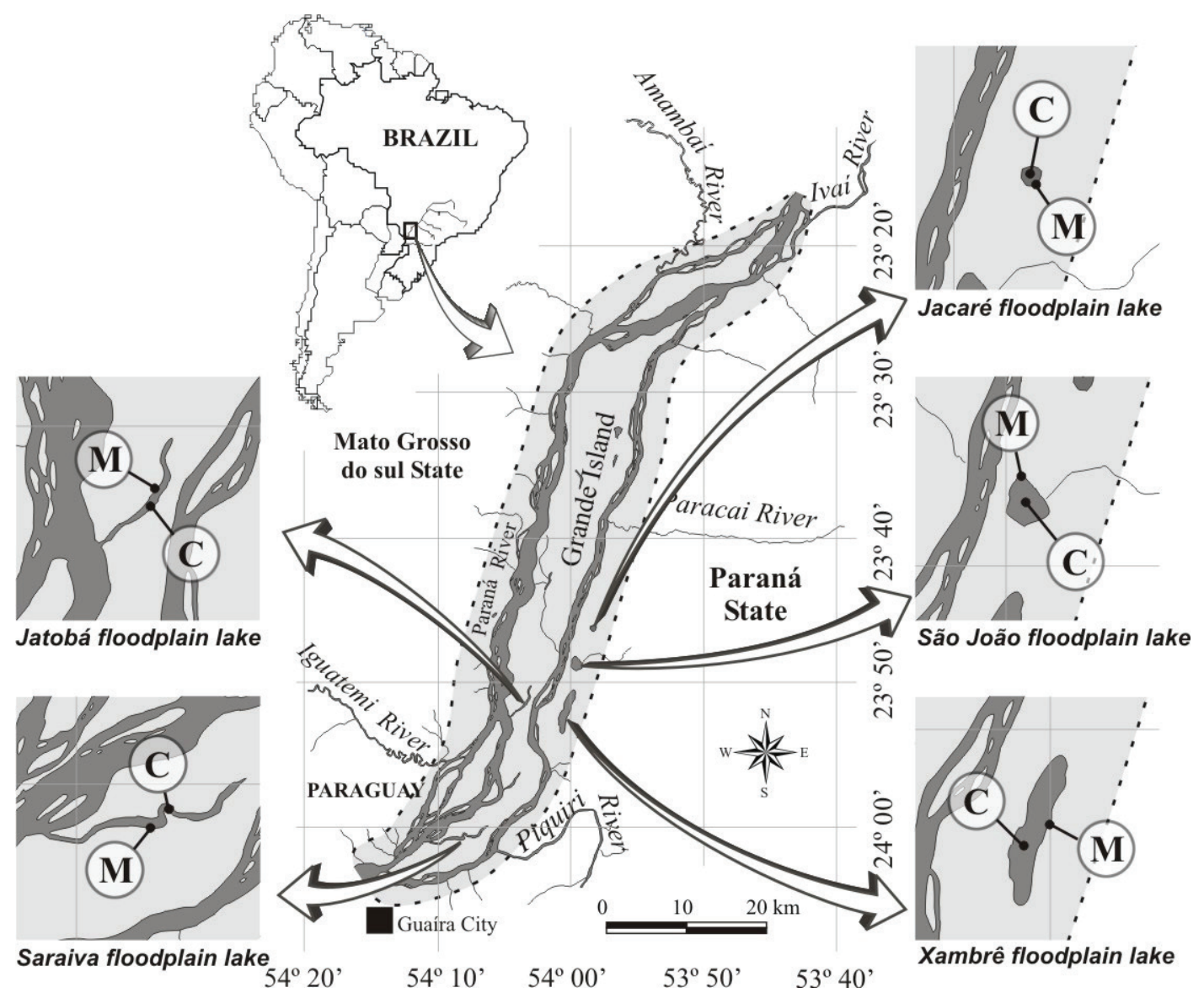

Fig. 1. Location of the sampling stations (floodplain lakes) in the Ilha Grande National Park, state of Paraná, Brazil (M, margin region; C, center region). 
lake located on the right margin of Ilha Grande, with a permanent connection with the Paraná River. This lake has approximately $10 \mathrm{~km}$ in length and $300 \mathrm{~m}$ in width at widest point. The water is dark but clean, and there is quite vegetation in the banks, mainly comprised by Eichhornia azurea (Pontederiaceae). A dense riparian forest surrounds the lake, and along with marshes and flooding areas form mosaics with the semi-deciduous seasonal forest (CORIPA, 2003). Jatobá Lake is also on the right margin of Ilha Grande, with similar features, but this lake is smaller than Saraiva, and may be isolated during the dry season. São João, Jacaré and Xambrê are isolated lakes located on the left margin of Paraná River, connected with the river during flood periods. Jacaré and Xambrê present an extensive floodplain area on the right margin, which separates them from the Paraná River.

Data sampling. We conduct the sampling on July 2010 using a modified Petersen grab $\left(0.0345 \mathrm{~m}^{-1}\right)$. We took at each sampling station six benthic samples near the margin (M) and six in the center (C), including five for biological analysis and one for granulometric texture analysis. Samplings in the Ilha Grande National Park was authorized by the Brazilian Environmental Agency (license number: 24156-1) in June 9, 2010.

We washed the samples collected for biological analysis in a sieve system (mesh: 2.0, 1.0 and $0.2 \mathrm{~cm}$ ). All organisms retained on 2.0 and $1.0 \mathrm{~cm}$ sieves were immediately picked out. The material retained on the 0.2 $\mathrm{cm}$ sieve was fixed in alcohol $80 \%$ and sorted under a stereoscopic microscope.
In order to obtain data of physical and chemical characteristics of each site (center and margin) from the lakes, water temperature $\left({ }^{\circ} \mathrm{C}\right)$, dissolved oxygen $\left(\mathrm{mg} . \mathrm{l}^{-1}\right.$; portable oximeter with YSI equipment) and depth (m; Ecosonda Hondex PS 7) were measured in situ. Water samples were taken from each point, kept into a thermal box with ice and taken to the lab where we measured the conductivity $\left(\mu \mathrm{S} . c m^{-1}\right.$; portable conductivimeter; Digimed), $\mathrm{pH}$ (pHmeter; Digimed), and turbidity (NTU; Quimis turbidimeter model Q-179). Granulometric texture was determined using methodology modified of WENTWORTH (1922) and organic matter content (OM) was obtained by incineration at $560^{\circ} \mathrm{C}$ during four hours.

Data analysis. Abiotic data (except temperature) from all sampling stations were used in a Principal Component Analysis (PCA) for data ordination in order to identify possible differences among the sampling stations, using PCORD 5.0 software (McCune \& MefFord, 1999). The axes were retained for interpretation using the KaiserGuttman criterion, i.e., those with eigenvalues higher than 1.0 .

Bivalve density (number of individuals $* 0.0345$ $\mathrm{m}^{-2}$ ), and the proportionate share of each taxa were graphically represented.

\section{RESULTS}

Abiotic analyses. In relation to the Principal Component Analysis (PCA), the first two axes explained $72.88 \%$ (axis $1=41.53 \%$ and axis $2=31.35 \%$ ) of total data

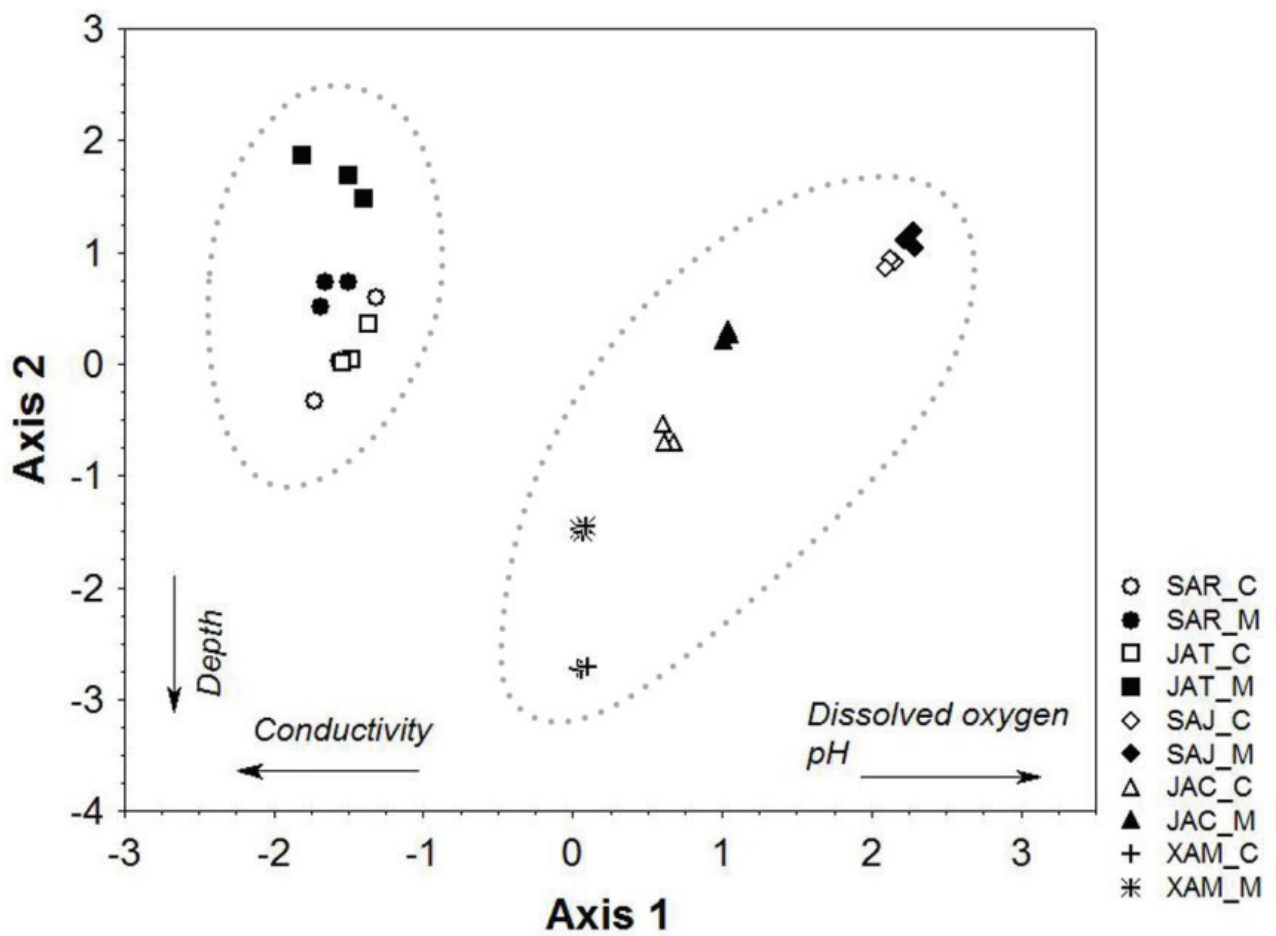

Fig. 2. Ordination diagram of the first two axes Principal Component Analysis (PCA) (SAR, Saraiva lake; JAT, Jatobá lake; SAJ, São João lake; JAC, Jacaré lake; XAM, Xambrê lake; C, Center Region; M, Margin Region). 
variability. In the axis 1 , dissolved oxygen and $\mathrm{pH}$ were positively correlated and conductivity, negatively. In the axis 2 , the depth was negatively correlated (Fig. 2).

The granulometric texture composition varied among the environments. We found in Jacaré and São João lakes highest percentage of mud, but in Saraiva lake high percentage of mud only in the margin, and highest percentage of sand in the center. We observed in Jatobá lake sand and pebbles (Figs 3,4). The percentage of organic matter was highest in Jacaré lake, followed by São João and Saraiva (Fig. 5).

Biotic analyses. We found higher values of density in São João-C with high density of Diplodon sp. (376.8 ind $/ \mathrm{m}^{2}$ ) and in São João-M we recorded high densities for Pisidium sterkianum (Pilsbry, 1897) $\left(347.8 \mathrm{ind} / \mathrm{m}^{2}\right)$. This was the only place where there was occurrence of two species of bivalves. In the Jatobá-C floodplain lake was recorded high density of $C$. fluminea $\left(144.9 \mathrm{ind} / \mathrm{m}^{2}\right)$ (Fig. 6).
When we analyzed the percentage of abundance, we did not reported any bivalves in Xambrê-M and $\mathrm{C}$, Saraiva-M and C and Jacaré-M. We observed the predominance of only one species in São João-M (Diplodon sp.), Jacaré-C (P. sterkianum), Jatobá-M (Diplodon sp.) and C (C. fluminea). Only in São João-C we observed de co-occurence of two species: P sterkianum (93\%) and Diplodon sp. (7\%) (Fig. 6).

\section{DISCUSSION}

Although the Principal Component Analysis (PCA) have formed two distinct groups in relation to abiotic factors, these differences separated the lakes only spatially (lakes located within the Island from those of the left bank of the Paraná River), and we did not find influences on the distribution of the freshwater bivalves. However, we observed that the presence of some species and their density
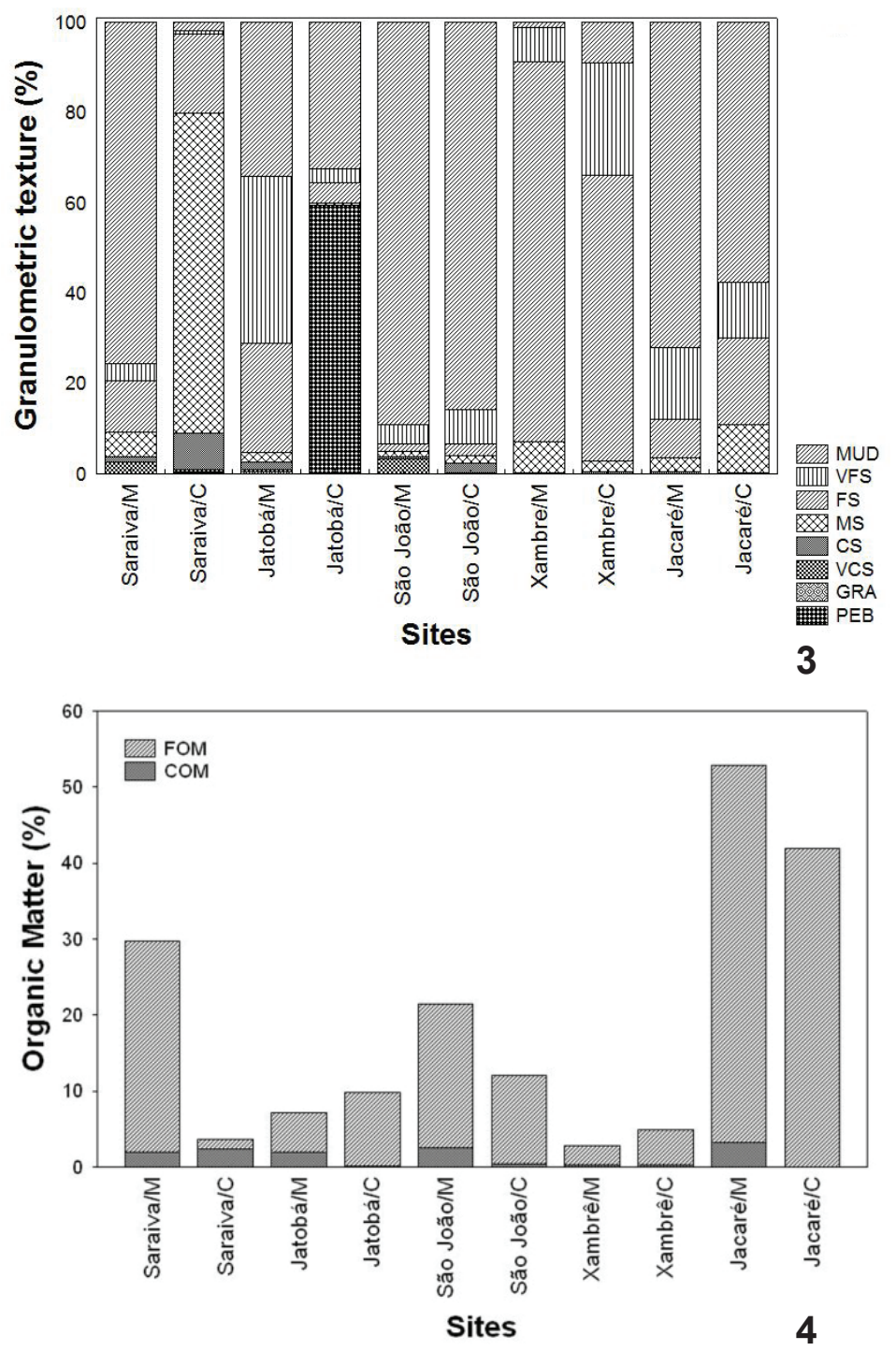

Figs 3, 4. Granulometric texture (3) and percentage of organic matter (4) from the studied lakes in the Ilha Grande National Park, state of Paraná, Brazil: PEB, pebbles; GRA, gravel; VCS, very coarse sand; CS, coarse sand; MS, medium sand; FS, fine sand; VFS, very fine sand; M, mud; FOM, fine organic matter; $\mathrm{COM}$, coarse organic matter. 


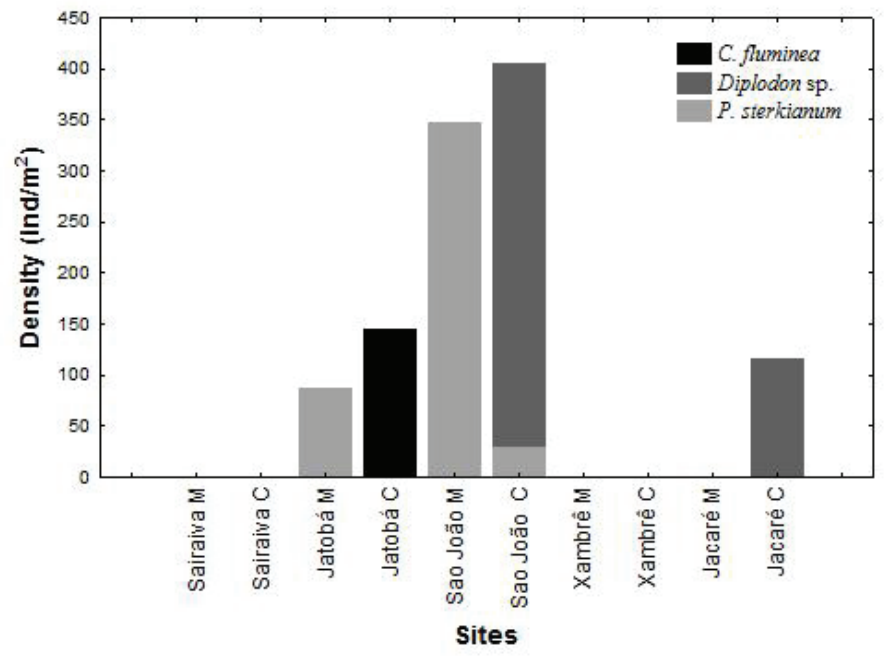

Fig. 5. Mean density of freshwater bivalves from the studied lakes in the Ilha Grande National Park, state of Paraná, Brazil (C, center; M, margin).

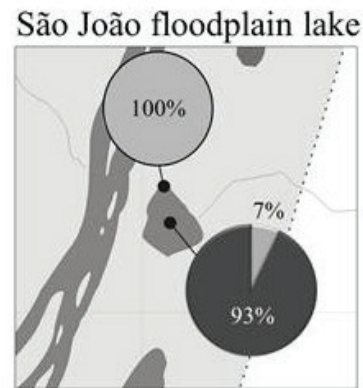

Jatobá floodplain lake

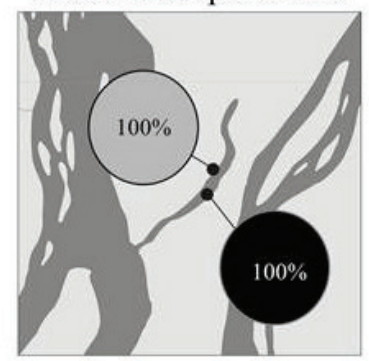

Xambrê floodplain lake
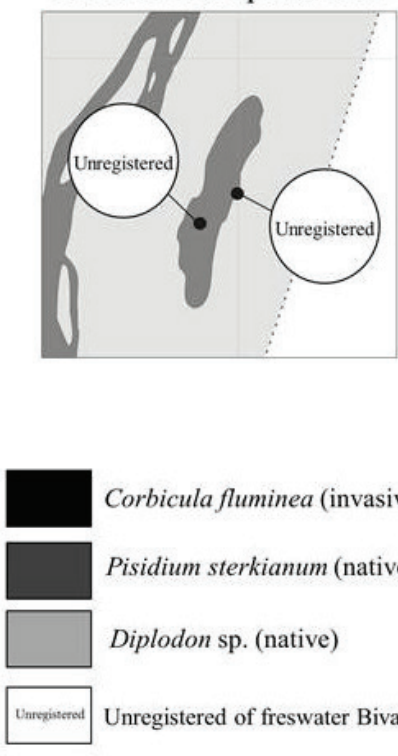

Corbicula fluminea (invasive)

Pisidium sterkianum (native)

Diplodon sp. (native)

Unregistered of freswater Bivalves
Jacaré floodplain lake

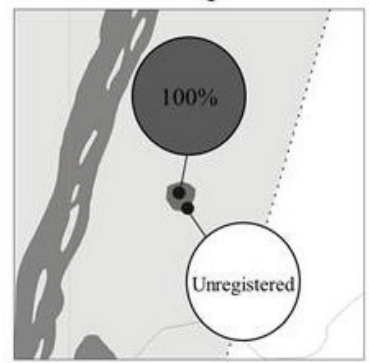

Saraiva floodplain lake

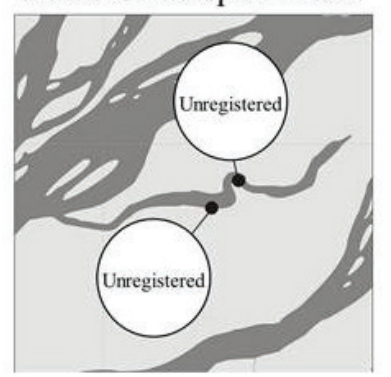

Fig. 6. Percentage of bivalves composition recorded in the central and marginal regions of the studied lakes in the Ilha Grande National Park, state of Paraná, Brazil (C, center; M, margin).

was more related to physical factors such as organic matter, particle size distribution than the existence of macrophyte banks in foodplain lakes.

We observed high densities of P. sterkianum in the margins of the São João e Jatobá lakes. In these regions, we registered predominantly fine sediments like mud and very fine sand, substrates that make it easier to digging and the posterior establishment of these small bivalves in the environment. Reinforcing this idea, Pfeifer \& Pitoni (2003) reported that the occurrence of snails of Pisidium is checked in environments where there are sediments composed of finer particles. Another factor that may have influenced the higher bivalve density was the presence of macrophytes banks in these floodplain lakes, by the increase of the local complexity, making it difficult to predation on these small bivalves. According to Pereira et al. (2000), the presence of macrophytes seems to be a decisive factor for the occurrence of some freshwater bivalve species, as Pisidium.

The presence of Diplodon sp. in São João-C and Jacaré-C was correlated with the high amount of organic matter, mainly fine particulate (FPOM) of these regions. According to PEREIRA et al. (2001), there is a preference of the species by these substrate types, which presents high organic matter contents. For the other hand, the high percentage of organic matter in Saraiva-M and Jacaré-M 
regions, there was not record of clam. Thus, these animals probably prefer central regions with higher depths.

The high density of Diplodon sp. demonstrates that these floodplain lakes could be possibly nursery for this species, because all specimens were small valve length, measured from 0.8 to $1.5 \mathrm{~cm}$. This fact could corroborating the importance of lakes from Ilha Grande National Park as refuges for these native species with fundamental role in maintaining biodiversity.

Contrasting with we expected, was recorded a high proportion of invasive bivalves in the Jatobá-C lake. This fact could be explained by the connection between this lake with the Paraná River, where have been noticed the colonization by many invasive species. The probable reason for establishing of $C$. fluminea in the Jatoba-C lake is based in a dependence on invasive species in relation to the sedimentology of the site, especially for juveniles. However, according VianNa \& Avelar (2010), there may be an increase of mortality of young in too finer sediment by obstruction or palial cavity, impeding the establishment of youth in this area. Thus, these results corroborate our work where this species was recorded at the site that had lower percentages of finer sediments.

The disconnected lakes (São João, Xambrê and Jacaré) seem to be more protected by the invasion of non-native species, such as $C$. fluminea. Although we not detected bivalves in the Xambrê and Saraiva lakes, the other environments showed representative densities of native species: P. sterkianum and Diplodon sp.

These results are important for the additional information in the study of freshwater bivalves. Although several studies have been conducted on the morphology, taxonomy, and distribution of Pisidium (ItUarte, 2000, 2001, 2004, 2006), few information is available about its ecology, especially to P. sterkianum (CÉSAR et al., 2012).

The occurrence of Diplodon was encouraging because the majority of species belonging to this genus appear on the national list of endangered species (MMA, 2003). The upper reaches of the Paraná River have not records of this species for many years, probably due to anthropogenic changes (e.g. dams) that have altered the environment and/or by competition with invasive species such as $C$. fluminea in the region.

According to TAKEDA et al. (2000) and BeAsLeY et al. (2003), in regions of Upper Paraná River and Pará, respectively, the sites occupied by C. fluminea spent a few years in densities much higher than the native species. VAughn \& SPOONER (2006) made a comparison between C. fluminea and the native bivalves, and demonstrated that the Asian species is smaller than the native, occur in large agglomerates, and has a higher filtration rate, which probably limits the availability of food in the water column for adults.

Sousa et al. (2009) warn that the effects caused by this invasive species can modify the environment. According these authors, the species is considered an invasive ecosystem engineer. Thus, this species should be considered very seriously in conservation initiatives, management and restoration of aquatic environments. Despite of the limited sampling conduct in the Ilha Grande National Park, we believe that the preservation of these areas is extremely important to maintaining the native bivalves species still present in the region. Furthermore, studies addressing the ecology of these animals are still needed to better understanding for their conservation and management.

Acknowledgements. The authors acknowledge the financial support of the Curso de Pós-Graduação em Ecologia de Ambientes Aquáticos Continentais / Universidade Estadual de Maringá to achieve discipline "Ecology of Zoobenthos". At the Instituto Chico Mendes para a Conservação da Biodiversidade (ICMBio - Parna Ilha Grande), Tércio Abel Pezenti for assistance during data collection; CORIPA, Department of Environment of Altonia and São Jorge do Patrocínio.

\section{REFERENCES}

Beasley, C.; Taglio, C. \& Figueiredo, W. B. 2003. The occurrence of the Asian clam Corbicula fluminea in the lower Amazon Basin. Acta Amazonia 33(22):317-323.

César, I. I.; Martín, S. M.; Rumi, A. \& Tassara, M. 2012. Mollusks (Gastropoda and Bivalvia) of the Multiple-Use Reserve Martín García Island, Río de la Plata River: biodiversity and ecology. Brazilian Journal of Biology 72(1):121-130.

CORIPA. 2003. Consórcio Intermunicipal para a Conservação do Remanescente das Várzeas do Rio Paraná e Áreas de Influência. Zoneamento Ecológico-Econômico (ZEE) das APA'S Intermunicipais de Ilha Grande - PR. Altônia. CD-ROOM.

Covich, A. P.; Palmer, M. A. \& Crowl, T. A. 1999. The role of benthic invertebrate species in freshwater ecosystems. BioScience 49:119127.

Dame, R. F. 1996. Ecology of Marine Bivalves: An Ecosystem Approach. Boca Raton, CRC Press. 272p.

ICMBıo - Instituto Chico Mendes de Conservação da Biodiversidade. 2008. Plano de Manejo para o Parque Nacional de Ilha Grande. Curitiba, DIREP. 752p.

. Unidades de Conservação do Bioma Mata Atlântica: Parna de Ilha Grande. 2012. Available at <http://www.icmbio.gov.br/portal/>. Accessed on 28 October 2012.

Ituarte, C. F. 2000. Pisidium taraguense and Pisidium pipoense, new species from Northeastern Argentina (Bivalvia: Sphaeriidae). Veliger 43(1):51-57.

2001. Pisidium chiquitanum new species from Santa Cruz de la Sierra, Bolivia (Bivalvia: Sphaeriidae). Nautilus 115(2):50-54. .2004. Sphaeriidae of Northwestern Argentina, including three new species of Pisidium (Bivalvia: Sphaeriidae). Nautilus 119(3):93-104.

Ituarte, C. \& Korniushin, A. V. 2006. Anatomical characteristics of two enigmatic and two poorly known Pisidium species (Bivalvia: Sphaeriidae) from Southern South America. Zootaxa 1338:33-47.

Mack, R. N.; Simberloff, D.; Lonsdale, W. M.; Evans, H.; Clout, M \& BAzZAZ, F. 2000. Biotic invasions: Causes, epidemiology, global consequences, and control. Ecological Applications 10:689-710.

McCune, B. \& MefFord, M. J. 1999. PC-ORD Multivariate Analysis of ecological data, Version 5. Gleneden Beach, MjM Software Design. Available at $<$ http://www.garyentsminger.com/ecosim/index.htm $>$. Accessed on 25 July 2010.

MMA - Ministério do Meio Ambiente. 2003. Available at <http:// www.meioambiente.es.gov.br/download/NovaListaFaunaAmeaca. mma2003>. Accessed on 6 November 2012.

Pereira, D.; Inda, L. A.; Consoni, J. M. \& Konrad, H. G. 2001. Composição e abundância de espécies de moluscos bentos marginal da microbacia do arroio Capivara, Triunfo, RS, Brasil. Biociências 9(1):3-20

Pereira, D.; Mansur, M. C. D. \& Pimpão, D. M. 2012. Identificação e diferenciação dos bivalves límnicos invasores dos demais bivalves 
nativos do Brasil. In: Mansur, M. C. D; Santos, C. P.; Pereira, D.; Paz, I. C. P.; Zurita, M. L. L.; Rodriguez, M. T. R.; Nehrke, M. V. \& Bergonci, P. E. A. eds. Moluscos límnicos invasores no Brasil: biologia, prevenção e controle. Porto Alegre, Redes Editora. p.75-94.

Pereira, D.; Veitenheimer-Mendes, I. L.; Mansur, M. C. D. \& Silva, M. C. P. 2000. Malacofauna límnica do sistema de irrigação da microbacia do arroio Capivara, Triunfo, RS, Brasil. Biociências 8(1):137-157.

Pfeifer, N. T. S. \& Pitoni, V. L. L. 2003. Análise qualitativa estacional da fauna de moluscos límnicos no delta do Jacuí, Rio Grande do Sul, Brasil. Biociências 11(2):145-158.

Souza, R.; Gutiérrez, J. L. \& Aldridge, D. C. 2009. Non-indigenous invasive bivalves as ecosystem engineers. Biological Invasions 11: $2367-2385$.

Stevaux, J. C.; Souza Filho, E. E.; Medeanic, S. \& Yamskikh, G. 2004. The quaternary history of the Paraná River and its floodplain. In: THомаZ, S. M.; Agostinho, A. A. \& Hahn, N. S. eds. The Upper Paraná
River and its Floodplain. Leiden, Backhuys Publishers. p. 31-53. Takeda, A. M.; Higuti, J.; Fujita, D. S. \& Bubena, M. R. 2000. Proliferação de uma espécie de bivalves invasora, Corbicula fluminea, na área alagável do Alto rio Paraná (Brasil). In: $1^{\circ}$ Seminário Brasileiro sobre Água de lastro. Arraial do Cabo, Instituto de Pesquisas Oceanográficas Almirante Paulo Moreira. 11p.

Vaughn, C. C. \& Spooner, D. E. 2006. Scale-dependent associations between native freshwater mussels and invasive Corbicula. Hydrobiologia 568(1):331-339.

Vianna, M. P. \& Avela, W. E. P. 2010. Ocorrência da espécie invasora Corbicula fluminea (Bivalvia, Corbiculidae) no rio Sapucaí (São Paulo, Brasil). Biotemas 23(3):59-66.

Vitousek, P. M.; D’Antonio, C. M.; Loope, L. L. \& Westbrooks, R. 1996. Biological invasions as global environmental change. American Scientist 84:468-478.

Wentworth, C. K. 1922. A escale of grade and class terms for clastic sediments. Journal of Geology 30:377-392. 